\title{
22. SIGNIFICANCE OF CLAY MINERALOGICAL AND GEOCHEMICAL DATA, WALVIS RIDGE, SOUTHEAST ATLANTIC, LEG 75, DEEP SEA DRILLING PROJECT ${ }^{1}$
}

\author{
Henri Maillot, Sédimentologie et Géochimie, E.R.A. C.N.R.S. 764, Université de Lille I-59655 Villeneuve \\ d'Ascq Cedex, France \\ and \\ Christian Robert, Géologie Marine, L.A. C.N.R.S. 41, Faculté des Sciences de Luminy, \\ 13288 Marseille Cedex 9, France
}

\begin{abstract}
Clay mineralogical and inorganic geochemical data give information on the evolution of both continental and marine paleoenvironments from late Albian to Pleistocene time. Specifically, the data indicate that: deposition of black shales occurred in an euxinic basin bounded by flat continental lowlands; that oxidation of the oceanic environment began during the Coniacian; that, from the Santonian to the Eocene, sediments were influenced by tectonic events and subsidence on the Walvis Ridge and on the African margin, as well as by the progressive deepening of the seafloor; that influences of the global climate cooling were present from early Miocene onwards; and that the development of the Benguela current system influenced sedimentation (since the Miocene principally). Fluctuations of the CCD were also determined.
\end{abstract}

\section{INTRODUCTION}

During Leg 75 of the Deep Sea Drilling Project (DSDP) two sites were drilled on the Walvis Ridge and in the Angola Basin (Fig. 1). The sediments recovered range from late Albian to late Pleistocene. Site characteristics are summarized in Table 1.

The purpose of this study is to reconstruct the paleoenvironmental conditions in the region under consideration, as indicated by clay mineralogical and inorganic geochemical variations. Similar approaches have been used previously to determine the following aspects of the paleoenvironmental evolution of the South Atlantic:

1) Formation of the South Atlantic basins (Maillot, 1979; Robert et al., 1979; Maillot, 1980; Maillot and Robert, 1980) and paleoenvironmental conditions during deposition of black shales (Chamley and Robert, 1982).

2) Cretaceous/Tertiary boundary events on the Atlantic margins (Chamley and Robert, 1979), on the Rio Grande Rise (Robert, 1981), and on the Walvis Ridge (Chamley et al., in press).

3) Cenozoic changes in climates and currents in the South Atlantic (Maillot and Robert, 1980; Robert, 1980; Maillot and Robert, in press).

4) Paleoenvironmental changes on the Falkland plateau from late Jurassic to Pleistocene (Robert and Maillot, in press).

\section{METHODS}

\section{Clay Mineralogy}

The study involved the analysis of 232 samples. In each, the sediment fraction $<63 \mu \mathrm{m}$ was decalcified in $0.2 \mathrm{~N}$ hydrochloric acid. The excess acid was removed by repeated centrifugations followed by homogenization. The $<2 \mu \mathrm{m}$ fraction was separated by decantation (set-

\footnotetext{
${ }^{1}$ Hay, W. W., Sibuet, J.-C., et al., Init. Repts. DSDP, 75: Washington (U.S. Govt. Printing Office).
}

tling time based on Stokes law); oriented aggregates were then made on glass slides. Three X-ray diffractograms were made as follows: (1) untreated sample, (2) glycolated sample, (3) sample heated for 2 hours at $490^{\circ} \mathrm{C}$. A C.G.R. Theta 60 diffractometer (copper $\mathrm{K} \alpha$ radiation focused by a quartz-curved crystal monochromator) was used at scan speeds of $1^{\circ} 2 \theta / \mathrm{mn}$, with all instrument settings kept constant. A receiving slit of $1.25 \mathrm{~mm}$ allowed a more precise resolution of poorly crystallized minerals.

The minerals included: chlorite, illite, irregular mixed layers (chlorite-smectite and illite-smectite), kaolinite, smectite, and attapulgite (palygorskite). Associated minerals were quartz, feldspar, cristobalite, and clinoptilolite in variable abundance.

Semiquantitative evaluations were based on peak heights and areas. The height of the 001 illite peak (glycolated sample) was taken as a reference. Compared to this value, smectite, palygorskite, and irregular mixed layers were corrected by multiplying their peak height by a factor of 1.5 to 2.5 , depending on their crystallinity, whereas well-crystallized kaolinite was corrected using a factor of 0.5 . Final data are given in percentages, the relative error being $\pm 5 \%$.

Illite crystallinity was the width, at half height, of the 001 illite peak $(10 \AA)$, on the glycolated sample. The relative abundance of smectite versus illite was obtained from the ratio of the 001 smectite $(18 \AA)$ and illite $(10 \AA)$ peaks on the glycolated sample.

\section{Geochemistry}

Samples were dried at $105^{\circ} \mathrm{C}$, then ground and homogenized. Next, $0.2 \mathrm{~g}$ were subjected to alkaline fusion, then dissolved in $\mathrm{HCl}$ and diluated to $100 \mathrm{ml}$. The treatment allowed gravimetric determination of $\mathrm{SiO}_{2}$ and spectrophotometric determination of $\mathrm{CaO}, \mathrm{MgO}$, $\mathrm{Al}_{2} \mathrm{O}_{3}$, and $\mathrm{Fe}_{2} \mathrm{O}_{3}$ (by atomic absorption). Another $2 \mathrm{~g}$ of each sample were submitted to fluoroperchloric treatment, then dissolved in $\mathrm{HCl}$ and diluted to $100 \mathrm{ml}$. The dilution was used for the colorimetric analysis of $\mathrm{TiO}_{2}$, the spectrophotometric analysis of $\mathrm{Na}_{2} \mathrm{O}$ and $\mathrm{K}_{2} \mathrm{O}$ (by emission) and also of $\mathrm{Mn}, \mathrm{Zn}, \mathrm{Li}, \mathrm{Ni}, \mathrm{Cr}, \mathrm{Sr}, \mathrm{Co}, \mathrm{Cu}, \mathrm{Pb}, \mathrm{V}$, and $\mathrm{Cd}$ (by atomic absorption). The emission and atomic absorption apparatus was a type 503 Perkin-Elmer spectrophotometer using the following methods: (1) base solution for major elements, (2) complex synthetic solution for trace elements to which $5 \%$ of lanthanum in hydrochloric solution was added.

\section{GENERAL RESULTS}

\section{Clay Mineralogy}

Clay mineral assemblages from these sites show the absence of burial diagenetic modifications. There is nei- 


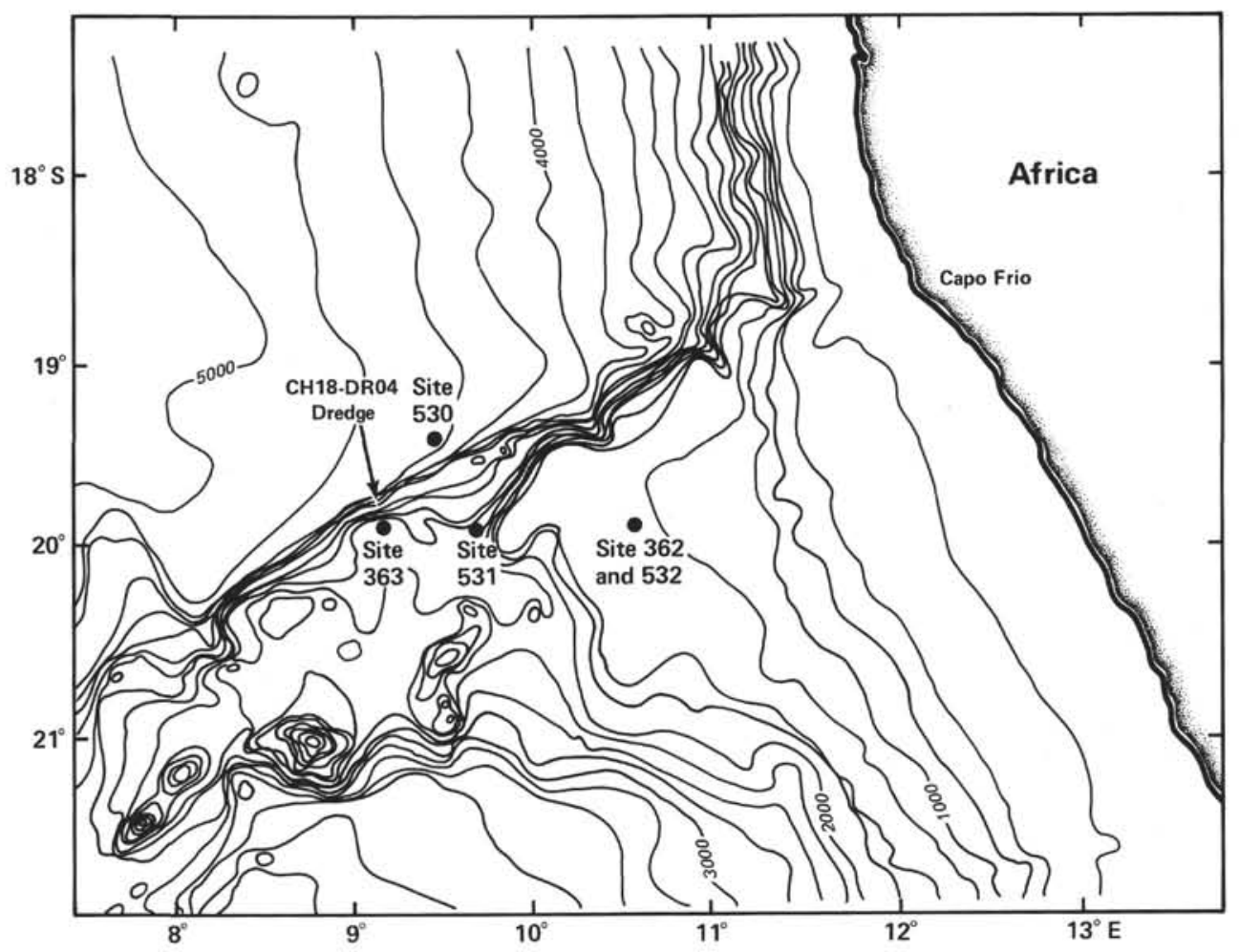

Figure 1. Site location map, Sites 362, 363 and Sites 530, 531, and 532.

Table 1. General site characteristics, Leg 75.

\begin{tabular}{|c|c|c|c|c|c|c|c|}
\hline \multirow[b]{2}{*}{ Site } & \multirow[b]{2}{*}{ Latitude } & \multirow[b]{2}{*}{ Longitude } & \multirow{2}{*}{$\begin{array}{l}\text { Water } \\
\text { depth } \\
\text { (m) }\end{array}$} & \multirow{2}{*}{$\begin{array}{l}\text { Penetration } \\
\text { (m) }\end{array}$} & \multicolumn{2}{|c|}{$\begin{array}{l}\text { Number of } \\
\text { samples }\end{array}$} & \multirow{2}{*}{$\begin{array}{l}\text { Oldest } \\
\text { sediment } \\
\text { recovered }\end{array}$} \\
\hline & & & & & Min. & Chem. & \\
\hline 530 & $19^{\circ} 11.26^{\prime} \mathrm{S}$ & $9^{\circ} 23.15^{\prime} \mathrm{E}$ & 4,629 & 1,121 & 168 & 82 & late Albian \\
\hline 532 & $19^{\circ} 44.61^{\prime} \mathrm{S}$ & $10^{\circ} 31.13^{\prime} \mathrm{E}$ & 1,331 & 742 & 64 & 34 & late Miocene \\
\hline
\end{tabular}

ther a progressive transition from smectite to mixed layers and illite, nor a reduction in illite crystallinity with increased depth at these DSDP sites. For comparison, influences of burial diagenesis on clay minerals are mentioned by Dunoyer (1969) in deeper boreholes.

Since there is no evident relationship between lithology and clay mineralogy, and since terrigenous components are abundant in these sediments, clay particles are considered to be essentially of detrital origin, formed in soils and by continental weathering as is the case in the North Atlantic (Chamley, 1979) and in other parts of the South Atlantic (Robert et al., 1979; Robert, 1981; Robert and Maillot, in press).

In Cretaceous sediments, large amounts of well-crystallized smectite, similar to the pedogenic smectite presently originating in African regions (Paquet, 1969) are present. That points to the existence of a globally warm continental climate, in agreement with the data compiled by Frakes (1979). The following aspects characterize clay mineral assemblages produced during long periods of constant warm climatic conditions (Millot, 1964; Chamley, 1979; Robert et al., 1979): (1) chlorite, illite, and mixed-layer minerals result principally from the direct erosion of rocks and from moderate continental weathering; (2) kaolinite is derived from soils developed in sloping and well-drained upstream areas; (3) smectite comes mainly from deep soils in downstream areas of continental drainage basins, where relief is low and drainage poor; (4) palygorskite (attapulgite) is derived mainly from sediments of confined coastal basins. The Santonian to Eocene sediments recovered during Leg 75 show the increasing importance of direct erosion of rocks, moderate continental weathering, and the presence of coastal confined basins.

In Cenozoic sediments, and especially since the late Eocene, the abundance of chlorite, illite, and mixed layers increase progressively, following the general climate cooling (Chamley, 1979) and the latitudinal zonation of climates and soils (Goldberg and Griffin, 1964; Pedro, 1968). The distribution of the clay minerals in the ocean is affected by several factors, the most important being the influence of oceanic water masses and circulation (Robert, 1980). In the Plio-Pleistocene sediments of the South Atlantic, intermediate water masses are enriched in illite and mixed layers originating from temperate areas; North Atlantic Deep Water is marked by kaolinite from equatorial regions; and Antarctic Bottom Water contains an important proportion of smectite. The general climatic trend is present with fluctuations in the abundance of the minerals in the Cenozoic sediments recovered during Leg 75.

\section{Geochemistry}

In oceanic sediments, $\mathrm{Fe}$ and $\mathrm{Mn}$ accumulations originate from detritic (fine or coarse fractions), hydrogenous, biogenic, or volcanogenic sources or by diagenetic processes (Elderfield, 1977). Despite these various possible origins, it seems that the relative abundances of $\mathrm{Fe}$ 
and $\mathrm{Mn}$ are significant for paleoenvironmental study (Turekian, 1965; Boström et al., 1972; Maillot, 1980; Maillot and Robert, 1980). Krashnaswami (1976) considered $\mathrm{Fe}-\mathrm{Mn}$ values higher than concentrations in a typical detrital shale to indicate an authigenic influence in the sediment formation. He used the index

$$
\mathrm{Mn}^{*}=\log \left[\frac{\text { Mn sample }}{\mathrm{Mn} \text { shale }} / \frac{\mathrm{Fe} \text { sample }}{\mathrm{Fe} \text { shale }}\right]
$$

where values of $\mathrm{Mn}$ shale and $\mathrm{Fe}$ shale are given by Boström et al. (1976). The variations in this index show the influence of oceanic basalts and oxidizing currents.

$\mathrm{Al}$ is principally related to the detritic minerals. An index proposed by Bostrom $(1969,1970)$ permits the recognition of detrital particles: $\mathrm{D}^{*}=\mathrm{Al} / \mathrm{Al}+\mathrm{Fe}+$ $\mathrm{Mn}$, associated with $\mathrm{Si}^{*}=\mathrm{SiO}_{2} / \mathrm{Al}_{2} \mathrm{O}_{3}$ (siltstones, sandstones). $\mathrm{D}^{*}$ is close to 0.63 in typical terrigenous shales. A decrease of $\mathrm{D}^{*}$ indicates less significant continental influence on sedimentation. Very high values of $\mathrm{D}^{*}$ sometimes correspond to abundant kaolinite particles. $\mathrm{Si}^{*}$ expresses the excess $\mathrm{Si}$ (i.e., not associated with $\mathrm{Al}$ ). This silica can be from volcanogenic (ashes), biogenic (diatoms, radiolarians), or detritic (quartz) origin.

The ratios $\mathrm{Mg}^{*}=\mathrm{MgO} / \mathrm{Al}_{2} \mathrm{O}_{3}$ and $\mathrm{Fe}^{*}=\mathrm{Fe}_{2} \mathrm{O}_{3}$ / $\mathrm{Al}_{2} \mathrm{O}_{3}$ permit the interpretation of variations in $\mathrm{MgO}$ and $\mathrm{Fe}_{2} \mathrm{O}_{3}$ with respect to clay mineral abundances.

The index $\mathrm{Sr}^{*}=10^{3} \mathrm{Sr} / \mathrm{CaO}$ is generally related to processes of carbonate dissolution (Maillot and Robert, 1980 ). When the variations related to burial diagenesis or to the primary compositions of the carbonates are mathematically determined, $\mathrm{Sr}^{*}$ confirms the processes of carbonate dissolution as inferred by others methods (Maxwell et al., 1970; van Andel et al., 1977; Melguen, 1978; Melguen et al., 1978). Three sorts of dissolution appear:

1) Very high Sr*: This type of dissolution is present in organic rich sediments and depends on the intensity of the reduced sedimentary environment.

2) High $\mathrm{Sr}^{*}$ : In open marine and oxidizing environments, this type of dissolution appears in the vicinity of the carbonate compensation depth (CCD). High Sr* values result from the low solubility of $\mathrm{SrCO}_{3}$ compared with $\mathrm{CaCO}_{3}$ (Nekrassov, 1966) or form the partial adsorption of $\mathrm{Sr}$ by clay minerals (Baush, 1968).

3) Low $\mathrm{Sr}^{*}$ : This type of dissolution occurs when the sediment has been deposited above the CCD.

\section{ANGOLA BASIN, HOLES 530, 530A, 530B}

\section{Lithology (Fig. 2)}

The base of the sedimentary section consists of upper Albian, Cenomanian, lower Turonian, and Coniacian/Santonian red and green claystone, and marlstone with interbedded black shales. Under this sedimentary complex, the basement consists of fine-grained basalt containing veins and vugs filled with calcite.

The Santonian to Campanian interval is represented by volcanogenic sandstone, variegated red, green, and purple claystone, siltstone, and sandstone.
The Campanian to lower Maestrichtian sediments consist of mudstone, marlstone, clastic limestone, and siliciclastic sandstone. The upper Maestrichtian to Eocene interval is represented by a multicolored mudstone, marlstone, chalk, and clastic limestone. Sediments vary from nannofossil marl and ooze, diatom ooze, and debris-flow deposits to green and red mud from late Oligocene to Pleistocene.

\section{Clay Mineralogy (Fig. 2)}

Several mineralogical units can be distinguished at this site. From late Albian to Campanian (Cores 530A105 to 74 ), smectite is the major clay mineral (65 to $100 \%$ ), accompanied by chlorite ( 0 to $10 \%)$, illite (0 to $15 \%$ ), mixed-layers ( 0 to $10 \%$ ), and palygorskite ( 0 to $5 \%$ ). Quartz and feldspar are also present. This claymineral assemblage suggests a dominant influence of pedogenic detrital supply originating from flat coastal areas developed on subdued relief.

From Campanian to Eocene (Cores 530A-73 to 37), illite ( 0 to $50 \%)$, and palygorskite ( 0 to $70 \%)$ increase, while smectite (25 to $100 \%)$ decreases. Chlorite (0 to trace amounts) and mixed layers (0 to $15 \%)$ are also present, as well as quartz, cristobalite, and clinoptilolite. This clay mineral association indicates an important detrital supply from altered rocks, moderate continental weathering, and confined coastal basins. In Core 530A-72, the increase of illite $(45 \%)$ is sharp and very important. The greenish volcanogenic sandstones consist of $20 \%$ glauconite. In this level, clay minerals are probably influenced by diagenetic effects that occurred during the processes of glauconitization-i.e., transformation of clay minerals and/or neoformation of illite. If one considers the pelagic environment of the site, and the formation of glauconite in shallower environments as present Atlantic shelf (Odin and Giresse, 1972), glauconite at Site 530 is certainly redeposited.

In this unit, palygorskite is present in long, straight, or flexuous fibers, suggesting its formation close to the site (Plate 1). Moreover, the presence of coalescent fibers, growing at the periphery of dense particles, suggests that palygorskite probably developed partially by transformation processes, as shown by Trauth (1976) and was then removed by erosion in the ocean.

From the late Oligocene onward (Cores 530A-37 to 2 and $530 \mathrm{~B}-34$ to 1$)$, chlorite (0 to $5 \%$ ), illite (trace amounts to $30 \%$ ), mixed layers ( 0 to $20 \%$ ), and kaolinite $(0$ to $15 \%)$ increase progressively. At the same time, the abundance of smectite ( 35 to $95 \%$ ) diminishes and palygorskite ( 0 to trace amounts) disappears. Quartz and feldspar are also present. This progressive mineralogic trend is related to the Cenozoic climate cooling.

\section{Geochemistry (Fig. 2 and Tables 2 and 3)}

From Albian to Coniacian-Santonian (Cores 530A105 to 87), the geochemical facies have the characteristics of the typical black shales described by Vine and Tourtelot (1970), Natland (1978), and Maillot (1980). $\mathrm{C}_{\text {org }}, \mathrm{Cu}, \mathrm{Ni}, \mathrm{Zn}, \mathrm{Co}, \mathrm{Cr}$, and $\mathrm{V}$ increase simultaneously. Mean values obtained from five samples of black 


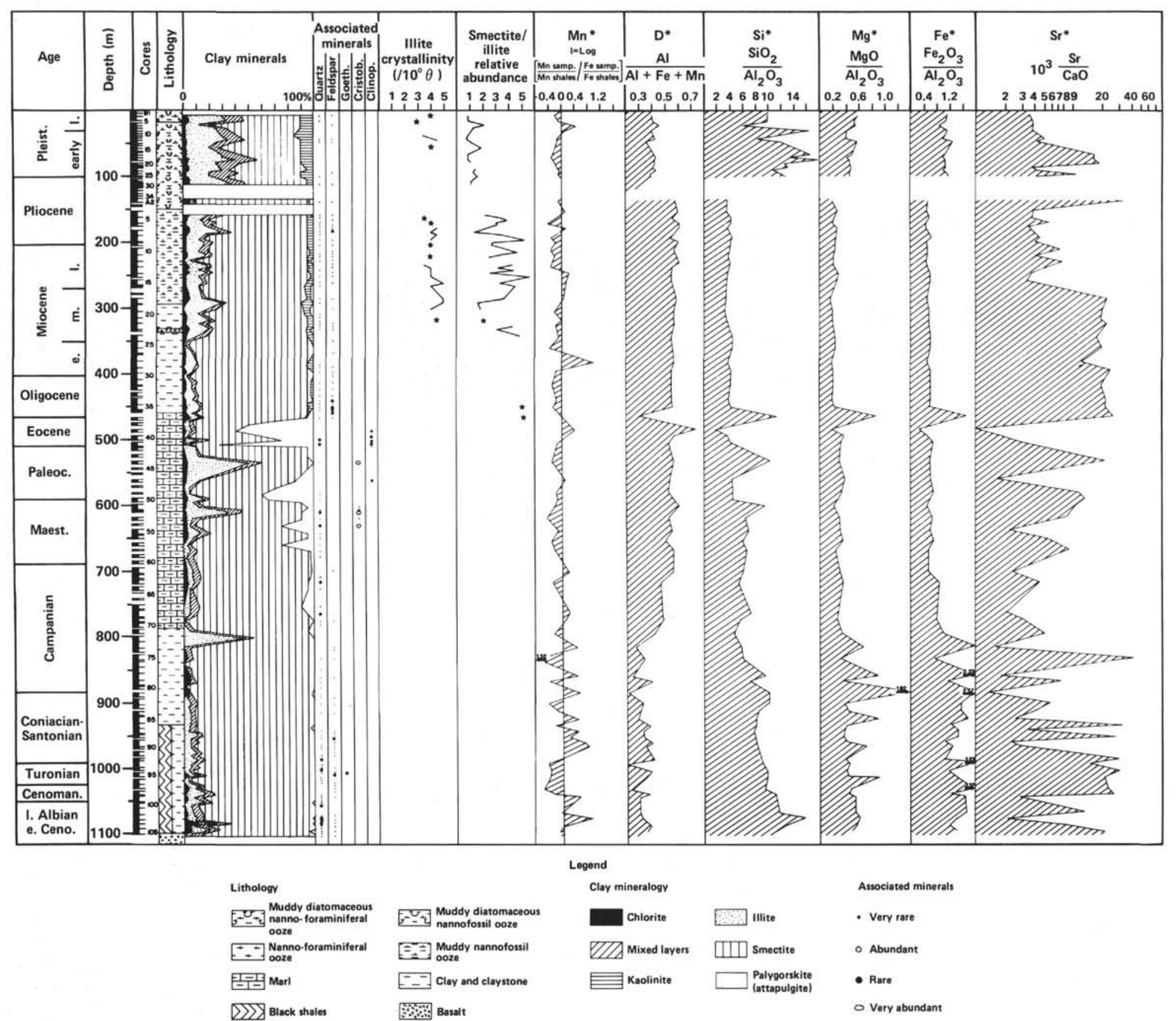

Figure 2. Lithology, geochemistry, and clay mineralogy, Site 530 . 
Table 2. Arithmetic means of geochemical analysis of five black shales.

\begin{tabular}{lrcc}
\hline Oxide & $(\%)$ & Element & (ppm) \\
\hline $\mathrm{SiO}_{2}$ & 53.44 & $\mathrm{Sr}$ & $170 \mathrm{ppm}$ \\
$\mathrm{Al}_{2} \mathrm{O}_{3}$ & 6.00 & $\mathrm{Cu}$ & $178 \mathrm{ppm}$ \\
$\mathrm{CaO}$ & 0.73 & $\mathrm{Ni}$ & $214 \mathrm{ppm}$ \\
$\mathrm{MgO}$ & 2.50 & $\mathrm{Co}$ & $135 \mathrm{ppm}$ \\
$\mathrm{Na} 2$ & 1.57 & $\mathrm{Zn}$ & $522 \mathrm{ppm}$ \\
$\mathrm{K}_{2} \mathrm{O}$ & 3.12 & $\mathrm{~Pb}$ & $32 \mathrm{ppm}$ \\
$\mathrm{TiO}_{2}$ & 1.14 & $\mathrm{~V}$ & $380 \mathrm{ppm}$ \\
$\mathrm{Fe}_{2} \mathrm{O}_{3}$ & 10.95 & $\mathrm{Cr}$ & $175 \mathrm{ppm}$ \\
\hline
\end{tabular}

shales (Samples 530A-89-4, $52 \mathrm{~cm}, 93-5,26 \mathrm{~cm}, 94-1$, $43 \mathrm{~cm}, 96-4,29 \mathrm{~cm}, 98-4,27 \mathrm{~cm}$ ) are given in Table 2.

$\mathrm{Sr}^{*}(24.25)$ depends on dissolution effects induced by the presence of organic matter.

The values of $\mathrm{Mn}^{*}$ fluctuate by 0.08 and are probably related to variations in physical and chemical properties of the paleoenvironment: volcanic events along the rift and anoxic conditions. $\mathrm{D}^{*}$ is small $(0.34)$, suggesting a scarce detritic influence of the clay fraction, principally or almost certainly related to volcanic events in the Walvis Ridge area.

$\mathrm{Si}^{*}(9.95)$ is very high at the base of the sedimentary column and progressively decreases from Albian to Co-

Table 3. Geochemical results, Hole 530A.

\begin{tabular}{|c|c|c|c|c|c|c|c|c|c|c|c|c|c|c|c|c|c|c|c|}
\hline $\begin{array}{c}\text { Sample } \\
\text { (level in } \mathrm{cm} \text { ) }\end{array}$ & $\begin{array}{l}\mathrm{SiO}_{2} \\
(\%)\end{array}$ & $\begin{array}{c}\mathrm{Al}_{2} \mathrm{O}_{3} \\
(\%)\end{array}$ & $\begin{array}{l}\mathrm{CaO} \\
(\%)\end{array}$ & $\begin{array}{c}\mathrm{MgO} \\
(\%)\end{array}$ & $\begin{array}{c}\mathrm{Na}_{2} \mathrm{O} \\
(\%)\end{array}$ & $\begin{array}{l}\mathrm{K}_{2} \mathrm{O} \\
(\%)\end{array}$ & $\begin{array}{l}\mathrm{TiO}_{2} \\
(\%)\end{array}$ & $\begin{array}{c}\mathrm{Fe}_{2} \mathrm{O}_{3} \\
(\%)\end{array}$ & $\begin{array}{c}\text { Mn } \\
(\mathrm{ppm})\end{array}$ & $\underset{(\mathrm{ppm})}{\mathrm{Zn}}$ & $\underset{\text { (ppm) }}{\mathrm{Li}}$ & $\begin{array}{c}\mathrm{Ni} \\
(\mathrm{ppm})\end{array}$ & $\underset{(\mathrm{ppm})}{\mathrm{Cr}}$ & $\begin{array}{c}\mathrm{Sr} \\
(\mathrm{ppm})\end{array}$ & $\begin{array}{c}\text { Co } \\
\text { (ppm) }\end{array}$ & $\underset{(\mathrm{ppm})}{\mathrm{Cu}}$ & $\begin{array}{c}\mathrm{Pb} \\
\text { (ppm) }\end{array}$ & $\underset{(\mathrm{ppm})}{\mathrm{V}}$ & $\underset{(\mathrm{ppm})}{\mathrm{Cd}}$ \\
\hline $2-2,32$ & 57.65 & 15.70 & 0.47 & 2.94 & 2.17 & 2.89 & 0.55 & 8.51 & 600 & 142 & 49 & 109 & 137 & 153 & 28 & 37 & 7 & 121 & 1 \\
\hline $4-4,140$ & 23.50 & 6.73 & 29.16 & 1.74 & 1.42 & 1.28 & 0.26 & 3.36 & 411 & 126 & 37 & 17 & 71 & 1132 & 13 & 24 & 81 & 53 & 2 \\
\hline $5-5,20$ & 36.35 & 8.41 & 16.20 & 1.85 & 1.85 & 1.93 & 1.09 & 5.00 & 258 & 132 & 41 & 45 & 76 & 611 & 11 & 21 & 34 & 68 & 2 \\
\hline $6-2,136$ & 51.55 & 12.05 & 4.99 & 2.39 & 2.39 & 2.62 & 1.48 & 5.83 & 237 & 118 & 55 & 41 & 121 & 268 & 6 & 23 & 20 & 89 & 1 \\
\hline $7-4,121$ & 17.75 & 4.74 & 34.72 & 1.21 & 1.25 & 1.14 & 0.24 & 2.23 & 305 & 73 & 28 & 16 & 53 & 1210 & 7 & 19 & 39 & 63 & 1 \\
\hline $8-5,7$ & 48.65 & 10.86 & 5.29 & 2.63 & 2.36 & 2.59 & 0.38 & 7.04 & 305 & 133 & 68 & 60 & 105 & 237 & 7 & 31 & 13 & 84 & 0 \\
\hline $9-1,111$ & 41.40 & 9.73 & 12.89 & 2.24 & 2.06 & 2.26 & 0.29 & 4.93 & 300 & 117 & 57 & 40 & 81 & 526 & 7 & 34 & 32 & 63 & 1 \\
\hline $10-6,5$ & 51.05 & 12.53 & 2.64 & 2.90 & 2.37 & 3.01 & 0.71 & 7.01 & 274 & 127 & 72 & 59 & 118 & 195 & 6 & 35 & 19 & 105 & 0 \\
\hline $11-5,32$ & 40.00 & 10.28 & 14.20 & 2.21 & 1.92 & 2.47 & 0.56 & 5.36 & 326 & 118 & 48 & 42 & 81 & 568 & 12 & 27 & 31 & 89 & 1 \\
\hline $12-5,10$ & 54.65 & 13.11 & 2.38 & 2.69 & 2.37 & 3.18 & 0.73 & 6.22 & 263 & 126 & 70 & 41 & 137 & 184 & 8 & 23 & 17 & 95 & 0 \\
\hline $13-3,93$ & 49.30 & 12.05 & 5.39 & 2.50 & 2.33 & 2.80 & 0.65 & 7.15 & 342 & 120 & 66 & 84 & 123 & 305 & 9 & 25 & 19 & 89 & 1 \\
\hline $14-3,64$ & 15.70 & 4.14 & 35.89 & 1.14 & 1.08 & 1.01 & 0.21 & 2.50 & 421 & 75 & 23 & 19 & 41 & 1353 & 10 & 22 & 45 & 53 & 2 \\
\hline $15-5,105$ & 17.75 & 4.84 & 33.81 & 1.25 & 1.04 & 1.20 & 0.25 & 2.93 & 437 & 73 & 26 & 32 & 48 & 1142 & 13 & 17 & 50 & 53 & 2 \\
\hline $18-5,43$ & 54.55 & 15.59 & 0.47 & 2.71 & 1.95 & 3.73 & 0.71 & 8.15 & 868 & 126 & 69 & 51 & 103 & 105 & 13 & 41 & 25 & 95 & 0 \\
\hline $20-3,60$ & 53.05 & 15.59 & 0.50 & 2.99 & 2.12 & 3.75 & 0.77 & 8.94 & 474 & 162 & 91 & 65 & 134 & 100 & 23 & 39 & 22 & 89 & 0 \\
\hline $21-5,125$ & 53.75 & 14.64 & 0.50 & 2.83 & 2.09 & 3.75 & 0.75 & 8.40 & 789 & 168 & 74 & 88 & 113 & 95 & 22 & 47 & 18 & 111 & 0 \\
\hline $22-4,85$ & 54.00 & 14.28 & 0.47 & 2.79 & 1.95 & 3.72 & 0.74 & 8.22 & 500 & 137 & 61 & 42 & 122 & 105 & 13 & 38 & 27 & 111 & 0 \\
\hline $24-6,73$ & 56.50 & 12.53 & 0.67 & 2.83 & 2.43 & 2.80 & 0.69 & 7.72 & 600 & 161 & 50 & 55 & 105 & 116 & 17 & 27 & 15 & 126 & 0 \\
\hline $26-3,51$ & 57.00 & 12.64 & 0.64 & 2.90 & 2.37 & 2.97 & 0.73 & 7.40 & 347 & 137 & 44 & 38 & 111 & 126 & 11 & 87 & 29 & 100 & 0 \\
\hline $28-5,25$ & 55.60 & 14.42 & 1.00 & 2.65 & 2.56 & 3.88 & 0.90 & 7.15 & 500 & 151 & 66 & 90 & 158 & 121 & 32 & 77 & 27 & 132 & 0 \\
\hline $30-2,17$ & 56.65 & 13.23 & 0.57 & 2.61 & 2.44 & 2.84 & 0.73 & 8.15 & 458 & 119 & 35 & 44 & 115 & 137 & 16 & 26 & 27 & 95 & 0 \\
\hline $32-3,8$ & 56.95 & 13.47 & 0.67 & 2.72 & 2.19 & 3.34 & 0.76 & 8.40 & 384 & 148 & 49 & 47 & 123 & 132 & 19 & 25 & 35 & 84 & 0 \\
\hline $34-6,66$ & 56.00 & 14.64 & 0.60 & 2.69 & 2.16 & 3.61 & 0.78 & 9.08 & 616 & 162 & 64 & 42 & 114 & 132 & 12 & 26 & 25 & 89 & 0 \\
\hline $36-1,82$ & 57.55 & 13.58 & 0.64 & 2.97 & 2.07 & 3.34 & 0.79 & 7.86 & 379 & 128 & 53 & 35 & 111 & 137 & 12 & 23 & 25 & 84 & 0 \\
\hline $37-3,41$ & 54.05 & 4.78 & 1.74 & 4.10 & 2.16 & 3.13 & 0.54 & 8.22 & 779 & 285 & 58 & 68 & 103 & 447 & 16 & 48 & 29 & 84 & 0 \\
\hline $39-2,83$ & 24.05 & 12.05 & 29.09 & 2.24 & 0.96 & 1.20 & 0.33 & 3.04 & 663 & 138 & 23 & 24 & 47 & 189 & 9 & 25 & 42 & 37 & 2 \\
\hline $40-4,39$ & 16.55 & 4.36 & 35.15 & 1.60 & 0.78 & 1.07 & 0.26 & 2.39 & 342 & 77 & 24 & 18 & 33 & 621 & 7 & 38 & 51 & 26 & 3 \\
\hline $41-3,122$ & 27.90 & 6.78 & 25.91 & 2.15 & 1.18 & 1.75 & 0.40 & 4.58 & 342 & 116 & 35 & 42 & 74 & 747 & 9 & 81 & 36 & 42 & 2 \\
\hline $44-2,44$ & 75.05 & 7.33 & 0.44 & 2.03 & 1.28 & 1.87 & 0.38 & 4.18 & 237 & 116 & 34 & 98 & 82 & 95 & 15 & 16 & 21 & 37 & 0 \\
\hline $49, \mathrm{CC}$ & 55.50 & 12.28 & 1.67 & 4.02 & 2.06 & 3.23 & 0.84 & 8.33 & 489 & 195 & 52 & 55 & 116 & 189 & 17 & 39 & 30 & 95 & 3 \\
\hline $50-4,90$ & 56.15 & 12.53 & 1.84 & 3.46 & 2.49 & 3.57 & 0.92 & 7.22 & 542 & 213 & 52 & 58 & 97 & 242 & 19 & 77 & 42 & 132 & 0 \\
\hline $51-5,120$ & 72.90 & 7.67 & 1.71 & 1.58 & 2.02 & 2.06 & 0.43 & 3.65 & 232 & 167 & 27 & 13 & 61 & 184 & 3 & 26 & 25 & 26 & 0 \\
\hline $53-2,63$ & 61.30 & 9.45 & 3.11 & 2.86 & 2.02 & 2.68 & 0.80 & 6.18 & 221 & 147 & 47 & 48 & 67 & 263 & 17 & 132 & 32 & 168 & 1 \\
\hline $55-5,63$ & 48.00 & 6.86 & 14.87 & 2.10 & 1.38 & 2.02 & 0.52 & 4.11 & 263 & 139 & 38 & 32 & 62 & 326 & 14 & 39 & 41 & 74 & 1 \\
\hline $57-2,68$ & 58.85 & 9.69 & 4.08 & 3.32 & 2.04 & 3.01 & 0.84 & 6.97 & 253 & 147 & 62 & 32 & 79 & 237 & 11 & 21 & 26 & 100 & 0 \\
\hline $59-2,24$ & 65.40 & 9.69 & 2.75 & 2.30 & 2.56 & 2.62 & 1.13 & 5.47 & 316 & 122 & 34 & 19 & 122 & 247 & 5 & 20 & 28 & 105 & 0 \\
\hline $62-4,63$ & 48.55 & 8.03 & 13.59 & 2.40 & 1.45 & 2.09 & 0.38 & 4.47 & 689 & 192 & 33 & 31 & 58 & 326 & 12 & 121 & 51 & 89 & 1 \\
\hline $64-2,118$ & 52.65 & 9.69 & 6.36 & 3.40 & 1.93 & 2.70 & 0.88 & 8.29 & 442 & 116 & 31 & so & 80 & 284 & 22 & 30 & 31 & 158 & 0 \\
\hline $68-5,30$ & 49.50 & 6.86 & 13.83 & 1.82 & 1.36 & 1.60 & 0.84 & 5.50 & 947 & 118 & 26 & 36 & 58 & 295 & 15 & 49 & 45 & 84 & 1 \\
\hline $70-2,57$ & 48.05 & 8.62 & 12.05 & 2.14 & 1.75 & 2.26 & 0.83 & 6.79 & 832 & 118 & 23 & 44 & 57 & 368 & 23 & 206 & 40 & 89 & 1 \\
\hline $72-2,54$ & 49.25 & 10.64 & 5.02 & 3.48 & 1.82 & 4.62 & 1.36 & 10.87 & 647 & 96 & 13 & 96 & 64 & 253 & 30 & 78 & 29 & 211 & 0 \\
\hline $74-2,28$ & 28.60 & 5.00 & 21.55 & 3.29 & 1.75 & 0.27 & 1.75 & 10.01 & 2484 & 191 & 30 & 47 & 63 & 347 & 32 & 83 & 12 & 226 & 1 \\
\hline $76-1,102$ & 55.30 & 9.19 & 1.05 & 2.83 & 2.49 & 0.30 & - & 6.72 & 58 & 126 & 17 & 106 & 236 & 437 & 96 & 89 & 40 & 256 & 0 \\
\hline $78-4,59$ & 39.25 & 4.19 & 16.02 & 3.67 & 1.31 & 1.75 & 0.79 & 9.36 & 2237 & 140 & 20 & 65 & 68 & 289 & 27 & 2 & 13 & 185 & 0 \\
\hline $79-5,9$ & 52.25 & 7.31 & 6.09 & 2.47 & 2.14 & 1.45 & 1.83 & 8.26 & 284 & 171 & 19 & 58 & 59 & 447 & 23 & 90 & 17 & 168 & 0 \\
\hline $81-1,119$ & 32.95 & 3.25 & 18.26 & 5.91 & 1.18 & 1.45 & 0.75 & 8.36 & 2658 & 142 & 15 & 45 & 46 & 247 & 29 & 2 & 13 & 94 & 0 \\
\hline $82-5,114$ & 57.55 & 5.75 & 5.46 & 2.11 & 1.69 & 2.65 & 0.52 & 8.94 & 284 & 168 & 30 & 62 & 77 & 321 & 12 & 12 & 25 & 114 & 0 \\
\hline $84-2,21$ & 49.00 & 5.81 & 9.48 & 2.47 & 1.85 & 2.65 & 1.23 & 9.11 & 563 & 127 & 34 & 73 & 85 & 395 & 13 & 63 & 29 & 111 & 0 \\
\hline $86-1,18$ & 42.15 & 5.26 & 10.88 & 4.61 & 1.45 & 2.65 & 0.92 & 9.29 & 2500 & 153 & 21 & 66 & 59 & 279 & 28 & 24 & 40 & 106 & 1 \\
\hline $87-4,67$ & 57.65 & 7.23 & 0.70 & 2.88 & 2.07 & 3.67 & 1.46 & 9.01 & 537 & 116 & 30 & 144 & 123 & 226 & 21 & 68 & 27 & 184 & 0 \\
\hline $88-2,114$ & 48.45 & 6.38 & 8.92 & 2.38 & 1.55 & 3.34 & 0.99 & 9.29 & 2537 & 123 & 26 & 46 & 81 & 311 & 11 & 32 & 35 & 129 & 0 \\
\hline $89-4,52$ & 56.85 & 7.25 & 0.73 & 2.59 & 1.72 & 3.91 & 1.36 & 10.51 & 1579 & 232 & 28 & 74 & 111 & 200 & 16 & 53 & 36 & 174 & 0 \\
\hline $90-3,28$ & 57.90 & 7.22 & 0.84 & 2.96 & 1.73 & 3.61 & 1.23 & 7.72 & 3500 & 112 & 31 & 98 & 100 & 200 & 55 & 109 & 29 & 188 & 0 \\
\hline $91-2,89$ & 48.65 & 5.94 & 6.72 & 4.20 & 1.45 & 3.01 & 1.06 & 7.65 & 4500 & 162 & 25 & 49 & 74 & 195 & 16 & 18 & 35 & 127 & 0 \\
\hline $93-5,26$ & 59.36 & 6.72 & 0.70 & 2.59 & 1.69 & 3.22 & 1.21 & 7.15 & 463 & 271 & 30 & 143 & 147 & 211 & 141 & 208 & 31 & 297 & 0 \\
\hline $94-1,43$ & 38.95 & 4.31 & 0.87 & 1.99 & 1.23 & 2.26 & 0.80 & 15.23 & 453 & 1500 & 26 & 562 & 212 & 132 & 323 & 375 & 34 & 858 & 7 \\
\hline $95-4,100$ & 63.20 & 6.53 & 0.59 & 2.67 & 1.72 & 3.01 & 1.19 & 7.65 & 311 & 129 & 37 & 51 & 97 & 179 & 19 & 139 & 22 & 221 & 0 \\
\hline $96-4,29$ & 59.50 & 6.13 & 0.80 & 2.66 & 1.67 & 2.77 & 1.23 & 8.58 & 268 & 232 & 36 & 88 & 166 & 174 & 35 & 121 & 17 & 321 & 0 \\
\hline $98-4,27$ & 52.55 & 5.59 & 0.56 & 2.67 & 1.55 & 3.46 & 1.08 & 13.26 & 347 & 375 & 31 & 206 & 242 & 132 & 158 & 132 & 43 & 253 & 0 \\
\hline $99-5,91$ & 66.75 & 6.06 & 0.45 & 2.74 & 1.38 & 2.98 & 0.99 & 7.51 & 379 & 181 & 32 & 28 & 72 & 121 & 5 & 63 & 12 & 128 & 0 \\
\hline $100-1,129$ & 58.70 & 5.31 & 5.39 & 2.87 & 1.09 & 2.86 & 0.71 & 8.79 & 2747 & 163 & 27 & 43 & 54 & 158 & 14 & 42 & 19 & 100 & 0 \\
\hline $102-6,32$ & 64.70 & 5.59 & 0.77 & 3.01 & 1.11 & 2.96 & 0.88 & 9.54 & 968 & 90 & 20 & 44 & 65 & 105 & 8 & 67 & 8 & 117 & 0 \\
\hline $103-4,121$ & 56.80 & 3.63 & 11.26 & 2.21 & 0.81 & 1.83 & 0.48 & 5.15 & 4000 & 92 & 34 & 15 & 39 & 242 & 5 & 34 & 21 & 74 & 0 \\
\hline $104-3,51$ & 66.35 & 5.29 & 1.33 & 2.98 & 1.17 & 2.80 & 0.83 & 6.43 & 574 & 111 & 37 & 22 & 56 & 116 & 5 & 53 & 18 & 107 & 0 \\
\hline $105-4,76$ & 62.75 & 5.66 & 0.63 & 2.78 & 1.60 & 3.49 & 1.50 & 8.04 & 621 & 100 & 44 & 41 & 64 & 137 & 16 & 60 & 24 & 130 & 0 \\
\hline
\end{tabular}


niacian times. $\mathrm{Fe}^{*}$ is close to 1.55 and $\mathrm{Mg}^{*}$ is approximately 0.48 . $\mathrm{Sr}^{*}(4.04)$ is relatively small in Cores 103 , 100,91 , and 88 and large (24.25) in the black shales. This trend can be explained by variations in the anoxicity of the black-shale environment.

From Coniacian-Santonian to Campanian (Cores 530A-86 to 76), calcareous components increase in the sediment: $\mathrm{SiO}_{2}, 46.92 \%$; $\mathrm{CaO}, 9.61 \%$. $\mathrm{Mn} *$ values fluctuate considerably above -0.11 . $\mathrm{D}^{*}$ maintains values (0.31) close to its Albian/Coniacian record, which probably expresses a volcanic influence on the sedimentation.

$\mathrm{Si}^{*}(8.45)$ decreases slightly, while $\mathrm{Mg}^{*}(0.72)$ and $\mathrm{Fe}^{*}(-1.65)$ maintain high values.

$\mathrm{Sr}^{*}(3.85)$ decreases progressively and reaches values which are common in marine carbonates.

During the late Campanian (Cores 530A-74 to 64), Mn* values fluctuate strongly above 0.06 and $\mathrm{D}^{*}$ increases progressively $(0.43)$. The sediment is characterized by both detrital and volcanic components. The volcanic influence decreases above Core 64 .

$\mathrm{Si}^{*}(5.71), \mathrm{Mg}^{*}(0.37)$, and $\mathrm{Fe}^{*}(1.09)$ decrease progressively. The presence of glauconite in the sediment may cause the increase of $\mathrm{Fe}^{*}$ (74.2 to 72.2$)$. $\mathrm{Sr}^{*}$ maintains values common in marine carbonates.

From late Campanian to the Pliocene (Cores 530A-62 to 2) $D^{*}$ is high (0.56), suggesting an increased influence of terrigenous components. $\mathrm{Mn}^{*}$ fluctuates between positive and negative values in response to the lack of an oxidizing environment.

The values of $\mathrm{Si}^{*}(4.80)$ suggest a clay mineral assemblage. Sr* values increase in the early Paleocene (Core 50, Section 9), at the top of the middle Paleocene (Core 44 ), from the middle Eocene to the top of the middle Miocene (Core 20, Section 4), and in the late Pliocene (Core 2, Section 2). These high values indicate that the area was affected by seafloor subsidence or by a rise in the CCD.

In the Pleistocene (Hole 530B, Core 27, Section 2 to Core 2, Section 1) Mn* values are close to those found in samples from late Campanian/Pliocene $(-0.08)$ and result from the lack of bottom oxidation. The excess of silica $\left(\mathrm{SiO}_{2}=11.78\right)$ is certainly related to the presence of siliceous microfossils. $\mathrm{Sr}^{*}$ values fluctuate considerably in the cores. When $\mathrm{Sr}^{*}$ is low (Core 44, Section 2 to Core 27, Section 2; Core 25, Section 2 to Core 22, Section 3; and Core 12, Section 2 to Core 2, Section 1), it characterizes marine carbonates devoid of dissolution processes. When $\mathrm{Sr}^{*}$ is high (Core 26, Section 2: $\mathrm{Sr}^{*}=$ 10.91; Core 20, Section 2 to Core 16, Section 2: $\mathrm{Sr}^{*}=$ 17.03), it is typical of dissolved marine carbonates (subsidence or a rise in the $\mathrm{CCD}$ ).

\section{WALVIS RIDGE, HOLES 532, 532B}

\section{Lithology (Fig. 3)}

The dominant lithologies are nannofossil ooze, marl, and clay and diatom sarl and smarl.

The bottom of the recovered section is represented by nannofossil marl, the middle part of the section consists of nannofossil diatom marl and sarl, and the top of the section is represented by nanno-foraminiferal and foram-nannofossil ooze and marl.

\section{Clay Mineralogy (Fig. 3)}

From late Miocene until late Pleistocene, the composition of the clay assemblage appears relatively homogeneous. Clay minerals include chlorite (trace amounts to $5 \%$ ), illite (5 to $40 \%$ ), mixed layers (trace amounts to $25 \%$ ), smectite (20 to $85 \%$ ), kaolinite (trace amounts to $10 \%$ ), and palygorskite (0 to trace amounts). Quartz and feldspar are also present. Fluctuations are present in the relative abundances of these minerals. The composition of the clay minerals assemblage depends mainly on climatic conditions during the late Cenozoic climate cooling.

\section{Geochemistry (Fig. 3 and Table 4)}

From late Miocene to Pleistocene, the chemical composition of the sediment appears homogeneous. $\mathrm{Mn}^{*}$ $(-0.25)$ shows a regular decrease from -0.17 to -0.25 and increases slightly during the Pleistocene $(-0.31)$. $D^{*}(0.58)$ is close to the values characteristic of terrigenous shales. $\mathrm{Si}^{*}(4.50)$ values typical of clay minerals reflect the increased influence of diatoms $\left(\mathrm{Si}^{*}=6.30\right)$ on sedimentation during late Pliocene and early Pleistocene.

Despite important lithologic variations (see Table 4) the chemical indices suggest that the paleoenvironment was always detritic and with low concentrations of transition elements. $\mathrm{Sr}^{*}$ is very close to the values recorded in marine carbonates where dissolution is absent.

\section{INFLUENCE OF VOLCANISM}

Geochemical data point to the presence of a strong volcanic influence in Albian to Santonian sediments at Site 530. Contrary to observations made in other regions of the South Atlantic (Maillot, 1980; Maillot and Robert, 1980; Maillot and Robert, in Debrabant et al., 1981), metallization does not increase in the sediment, because of the presence of an euxinic environment acting against precipitation of metallic oxides. $\mathrm{D}^{*}$ is a very close to the values recorded in volcanogenic clay species (Wedepohl, 1978). Clay mineralogical data show that smectite abundance does not increase significantly toward the bottom of the Hole 530A, where the sediment is in contact with the basalt. Generally, oceanic volcanogenic smectite is present a few centimeters above the basalt (Maillot and Robert, in Debrabant et al., 1981), but subaerial alteration of basalts can produce abundant smectite during a long period, as is the case on the Walvis Ridge during the Late Cretaceous (Chamley et al., in press). If one considers the location of Site 530, it appears that a part of the smectite present in Albian to Santonian sediments is volcanogenic, and the other part is possibly produced from removal of subaerial alteration of basalts on Africa or Walvis Ridge. However, the dominant part of the clay mineral assemblage, including smectite, seems to be from pedogenic origin, as suggested by the shape of the $\mathrm{X}$-ray diffractograms.

During Oligocene and early Miocene times, the occurrence of clays rich in volcanogenic components and con- 


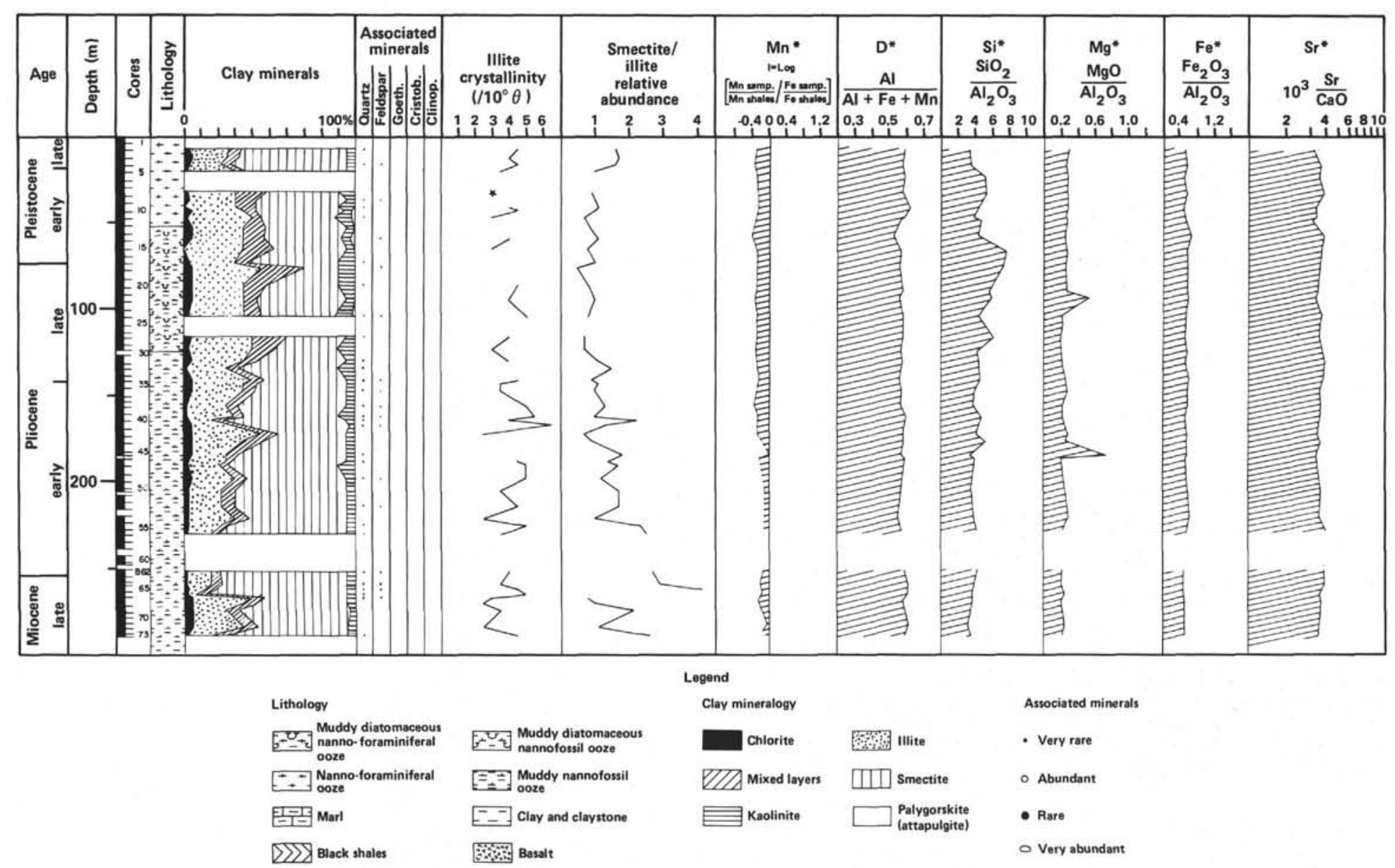

Figure 3. Lithology, geochemistry, and clay mineralogy, Site 532. 
Table 4. Geochemical results, Site 532.

\begin{tabular}{|c|c|c|c|c|c|c|c|c|c|c|c|c|c|c|c|c|c|c|c|}
\hline $\begin{array}{c}\text { Sample } \\
\text { (level in } \mathrm{cm} \text { ) }\end{array}$ & $\begin{array}{l}\mathrm{SiO}_{2} \\
(\%)\end{array}$ & $\begin{array}{c}\mathrm{Al}_{2} \mathrm{O}_{3} \\
(\%)\end{array}$ & $\begin{array}{l}\mathrm{CaO} \\
(\%)\end{array}$ & $\begin{array}{l}\mathrm{MgO} \\
(\%)\end{array}$ & $\begin{array}{c}\mathrm{Na}_{2} \mathrm{O} \\
(\%)\end{array}$ & $\begin{array}{l}\mathrm{K}_{2} \mathrm{O} \\
(\%)\end{array}$ & $\begin{array}{l}\mathrm{TiO}_{2} \\
(\%)\end{array}$ & $\begin{array}{c}\mathrm{Fe}_{2} \mathrm{O}_{3} \\
(\%)\end{array}$ & $\begin{array}{c}\text { Mn } \\
\text { (ppm) }\end{array}$ & $\underset{(\mathrm{ppm})}{\mathrm{Zn}}$ & $\underset{(\mathrm{ppm})}{\mathrm{Li}}$ & $\begin{array}{c}\mathrm{Ni} \\
(\mathrm{ppm})\end{array}$ & $\underset{(\mathrm{ppm})}{\mathrm{Cr}}$ & $\begin{array}{c}\mathrm{Sr} \\
(\mathrm{ppm})\end{array}$ & $\begin{array}{c}\mathrm{Co} \\
\text { (ppm) }\end{array}$ & $\underset{(\mathrm{ppm})}{\mathrm{Cu}}$ & $\underset{\text { (ppm) }}{\mathrm{Pb}}$ & $\begin{array}{c}\mathrm{V} \\
(\mathrm{ppm})\end{array}$ & $\underset{(\mathrm{ppm})}{\mathrm{Cd}}$ \\
\hline \multicolumn{20}{|l|}{ Hole 532} \\
\hline $2-3,86$ & 17.25 & 5.18 & 31.20 & 1.48 & 1.83 & 1.20 & 0.26 & 2.68 & 116 & 288 & 47 & 62 & 97 & 995 & 7 & 44 & 35 & 65 & 2 \\
\hline $4-3,105$ & 22.90 & 6.41 & 25.36 & 1.71 & 2.02 & 1.51 & 0.31 & 3.54 & 142 & 147 & 38 & 56 & 89 & 916 & 5 & 23 & 16 & 49 & 2 \\
\hline $6-2,52$ & 25.00 & 4.78 & 25.61 & 1.39 & 2.26 & 1.17 & 0.23 & 2.50 & 116 & 124 & 33 & 65 & 74 & 895 & 3 & 47 & 17 & 51 & 2 \\
\hline $8-2,104$ & 29.90 & 5.69 & 17.73 & 1.60 & 2.07 & 1.37 & 0.31 & 3.15 & 147 & 115 & 39 & 64 & 95 & 684 & 4 & 34 & 15 & 54 & 2 \\
\hline $10-3,55$ & 21.50 & 4.82 & 31.48 & 1.33 & 1.65 & 1.16 & 0.23 & 2.25 & 111 & 789 & 29 & 55 & 68 & 1042 & 6 & 19 & 28 & 37 & 3 \\
\hline $11-3,147$ & 24.40 & 6.44 & 22.74 & 1.62 & 2.07 & 1.58 & 0.31 & 3.32 & 147 & 118 & 52 & 72 & 89 & 768 & 4 & 59 & 25 & 60 & 3 \\
\hline $12-1,80$ & 28.10 & 6.01 & 25.19 & 1.60 & 2.00 & 1.45 & 0.30 & 3.47 & 147 & 551 & 45 & 72 & 92 & 784 & 5 & 33 & 26 & 52 & 3 \\
\hline $14-2,33$ & 38.20 & 8.75 & 11.47 & 2.18 & 2.36 & 2.14 & 0.46 & 5.79 & 205 & 155 & 70 & 98 & 108 & 447 & 2 & 81 & 18 & 74 & 2 \\
\hline $16-1,116$ & 29.35 & 3.85 & 26.97 & 1.06 & 2.12 & 1.02 & 0.20 & 2.14 & 95 & 82 & 25 & 51 & 68 & 984 & 4 & 25 & 26 & 41 & 3 \\
\hline $18-2,106$ & 41.50 & 5.72 & 17.07 & 1.49 & 2.49 & 1.55 & 0.29 & 3.32 & 147 & 100 & 39 & 55 & 68 & 611 & 1 & 42 & 24 & 52 & 2 \\
\hline $21-3,77$ & 26.80 & 4.69 & 28.26 & 1.25 & 1.82 & 1.20 & 0.24 & 2.54 & 116 & 78 & 27 & 31 & 55 & 979 & 6 & 21 & 39 & 53 & 1 \\
\hline $22-2,141$ & 31.80 & 5.31 & 20.11 & 2.93 & 2.01 & 1.42 & 0.26 & 3.15 & 132 & 101 & 33 & 52 & 56 & 674 & 3 & 40 & 24 & 57 & 1 \\
\hline $24-3,80$ & 33.05 & 7.50 & 18.40 & 1.60 & 2.01 & 1.88 & 0.35 & 4.11 & 200 & 109 & 45 & 52 & 83 & 684 & 4 & 53 & 63 & 74 & 1 \\
\hline $25-2,48$ & 35.35 & 6.97 & 18.92 & 1.50 & 2.02 & 1.79 & 0.34 & 3.75 & 168 & 100 & 42 & 39 & 66 & 674 & 4 & 33 & 21 & 63 & 1 \\
\hline $27-2,130$ & 43.60 & 7.09 & 14.97 & 1.45 & 2.12 & 1.82 & 0.33 & 3.79 & 179 & 95 & 44 & 28 & 66 & 526 & 1 & 31 & 13 & 59 & 2 \\
\hline $29-3,19$ & 35.80 & 8.50 & 14.69 & 1.81 & 2.19 & 2.16 & 0.42 & 4.83 & 205 & 125 & 61 & 64 & 97 & 547 & 5 & 68 & 21 & 79 & 1 \\
\hline $31-3,15$ & 26.70 & 6.03 & 26.72 & 1.31 & 1.58 & 1.51 & 0.29 & 3.22 & 153 & 1370 & 37 & 41 & 88 & 1021 & 7 & 24 & 23 & 54 & 2 \\
\hline $34-2,51$ & 32.90 & 7.29 & 19.17 & 1.84 & 1.87 & 1.88 & 0.42 & 4.29 & 184 & 124 & 48 & 73 & 114 & 721 & 6 & 44 & 16 & 65 & 1 \\
\hline $36-1,69$ & 23.35 & 5.86 & 28.51 & 1.67 & 1.53 & 1.51 & 0.30 & 3.32 & 158 & 106 & 35 & 43 & 80 & 1021 & 7 & 27 & 16 & 57 & 2 \\
\hline $38-2,36$ & 29.40 & 7.77 & 21.72 & 1.70 & 1.62 & 1.93 & 0.35 & 4.47 & 179 & 256 & 44 & 59 & 98 & 784 & 6 & 45 & 9 & 74 & 1 \\
\hline $40-2,48$ & 28.60 & 6.01 & 26.76 & 1.33 & 1.65 & 1.87 & 0.44 & 3.04 & 163 & 141 & 49 & 66 & 111 & 953 & 7 & 45 & 26 & 71 & 1 \\
\hline $42-2,82$ & 23.45 & 5.65 & 29.98 & 1.59 & 1.35 & 1.43 & 0.28 & 3.11 & 147 & 200 & 32 & 30 & 60 & 1021 & 11 & 19 & 8 & 51 & 2 \\
\hline $43-2,77$ & 20.65 & 3.97 & 32.36 & 1.04 & 1.50 & 1.01 & 0.19 & 2.14 & 132 & 77 & 23 & 32 & 53 & 1158 & 9 & 21 & 24 & 51 & 3 \\
\hline $45-2,39$ & 14.20 & 4.14 & 33.23 & 3.03 & 1.15 & 1.05 & 0.18 & 2.32 & 211 & 71 & 25 & 15 & 49 & 1105 & 8 & 8 & 17 & 55 & 3 \\
\hline $46-2,46$ & 31.90 & 8.09 & 20.29 & 1.69 & 1.43 & 1.48 & 0.29 & 4.29 & 189 & 407 & 39 & 33 & 77 & 789 & 9 & 18 & 13 & 63 & 2 \\
\hline $50-1,6$ & 21.85 & 6.25 & 29.63 & 1.53 & 1.36 & 1.51 & 0.31 & 3.57 & 247 & 378 & 36 & 33 & 77 & 1074 & 11 & 21 & 24 & 65 & 2 \\
\hline $54-1,87$ & 11.05 & 2.93 & 40.23 & 0.84 & 1.15 & 0.72 & 0.15 & 1.82 & 126 & 83 & 19 & 29 & 46 & 1442 & 5 & 18 & 16 & 42 & 3 \\
\hline $56-2,24$ & 27.05 & 6.44 & 25.33 & 1.50 & 1.45 & 1.61 & 0.35 & 3.65 & 242 & 136 & 49 & 44 & 82 & 1021 & 9 & 33 & 11 & 77 & 2 \\
\hline \multicolumn{20}{|l|}{ Hole 532B } \\
\hline $62-1,120$ & 27.05 & 6.33 & 26.24 & 1.38 & 1.33 & 1.48 & 0.34 & 3.32 & 205 & 163 & 43 & 35 & 71 & 1021 & 8 & 25 & 21 & 68 & 2 \\
\hline $64-2,14$ & 23.35 & 5.88 & 29.56 & 1.26 & 1.33 & 1.33 & 0.31 & 2.82 & 158 & 184 & 36 & 25 & 65 & 1168 & 7 & 18 & 38 & 62 & 3 \\
\hline $66-1,69$ & 21.60 & 5.91 & 30.78 & 1.48 & 1.16 & 1.22 & 0.28 & 2.79 & 174 & 68 & 36 & 24 & 58 & 1126 & 7 & 10 & 24 & 62 & 2 \\
\hline $67-2,51$ & 26.45 & 7.07 & 25.47 & 1.48 & 1.42 & 1.55 & 0.33 & 3.79 & 189 & 102 & 43 & 48 & 67 & 953 & 7 & 44 & 22 & 95 & 3 \\
\hline $71-2,83$ & 11.05 & 3.46 & 40.23 & 0.82 & 1.06 & 0.78 & 0.15 & 1.68 & 126 & 418 & 19 & 23 & 43 & 1432 & 6 & 17 & 24 & 39 & 3 \\
\hline $73-2,20$ & 1570 & 4.50 & 35.68 & 0.99 & 1.08 & 1.02 & 0.27 & 2.36 & 132 & 78 & 28 & 30 & 54 & 1247 & 7 & 20 & 16 & 59 & 3 \\
\hline
\end{tabular}

taining 95 to $100 \%$ of well-crystallized smectite in two samples leads to the same conclusion. Here, volcanic particles do not influence the variations of the geochemical indices in an important manner.

\section{CHARACTERS OF EUXINIC SEDIMENTS}

\section{Black Shales}

At Site 530, the base of the sedimentary column consists of a late Albian black-shale facies overlying an oceanic basalt and a clay assemblage including abundant well-crystallized smectite. This sedimentary facies extends to the Coniacian-Santonian. There is no close relation between the variations of clay minerals, lithology, and organic matter. These data differ from results obtained on Mediterranean sapropels, where decreases in palygorskite or smectite, as well as corrosion of phyllite particles, occur (Sigl et al., 1978). As a consequence, the deposition environment of black shales is characterized by diagenesis of clay minerals, as observed in other regions of the South Atlantic (Robert et al., 1979; Robert and Maillot, in press). As there is no preponderant influence of volcanism on clay minerals at Site 530, the great abundance of smectite expresses primarily the morphology of continental coastal areas. It is suggested that, during late Albian, the region of Site 530 was in the vicinity of flat continental lowlands, where deep gray soils developed on both the African continent and Walvis Ridge, emergent for the most part. These implications are consistent with the results previously obtained at Site 363 on the Walvis Ridge (Robert et al., 1979) and suggest that the entire area under consideration was tectonically passive by this epoch.

The sediments deposited from Albian to ConiacianSantonian are also characterized by strong abundances of $\mathrm{Cu}, \mathrm{Ni}, \mathrm{Zn}, \mathrm{Co}, \mathrm{Cr}$, and $\mathrm{V}$, in agreement with data obtained at Sites 363 and 364 on the Walvis Ridge and in the Angola Basin (Maillot, 1980).

\section{Late Cenozoic Organic Sediments}

Occurrences of organic matter are present at Sites $\mathbf{5 3 0}$ and 532 from Late Miocene to late Pleistocene. The abundance increases progressively from the late Miocene to the end of early Pliocene, and then decreases (Meyers, Brassell, Huc, this vol.). With respect to clay minerals, abundances of chlorite, illite, and mixed layers increase then decrease contemporaneously with the general trend of organic matter accumulations. During the same period, metallization effects are very weak. Oxygen deficiency in the environment probably prevented the precipitation of any metallic oxide. The abundance of organic carbon, depending on planktonic productivity, increased with the development of the Benguela upwelling system during the late Miocene (DiesterHaass and Schrader, 1979; Siesser, 1980). Probably starting during early Oligocene (Peypouqet and Benson, in preparation), the intensity of this upwelling increased as a result of climatic cooling, which led to the development of the Antarctic ice-sheet and oceanic circulation. Thus, organic matter, as well as illite and mixed 
layers, which express global climatic and oceanic variations, are more abundant at the end of the early Pliocene, a time when the Antarctic ice sheet reached its greatest extension (Mercer, 1978). Moreover, chlorite, illite, and mixed layers in the oceanic areas subjected to the Benguela system could originate in large part from erosional processes in the relatively arid southwest Africa, as shown by Diester-Haass and Chamley (1980) for sediments along the arid coast of northwest Africa.

\section{TECTONICS AND SUBSIDENCE}

From Santonian to late Eocene, increases in the amounts of illite and palygorskite point to the importance of erosion of altered rocks and moderate weathering, as well as of confined coastal basins. Clay mineralogical variations suggest the presence of a continental topography rejuvenated by tectonism, during a period when marginal tectonic events are present all around the Atlantic Ocean, in relation to changes in the direction of ocean opening and increases in the velocity of spreading (Sibuet and Mascle, 1978; Chamley and Robert, 1979). The marginal tectonic activity induces the erosion and removal of elements originating from the continental shelf (i.e., glauconitic sediments), confined coastal basins (i.e., palygorskite), flat downstream lowlands (i.e., smectite), and continental reliefs (i.e., illite and mixed layers). Close to Site 530, in the Rio Grande Rise and Walvis Ridge areas (Robert, 1981, Maillot and Robert, in press), tectonic events, as well as development and removal of semienclosed confined basins appear more influential on sedimentation. They are related to the progressive subsidence of these oceanic barriers and to the deepening of the seafloor, and then disappear when the structures become almost totally submerged.

\section{INFLUENCES OF CLIMATE, CURRENTS, AND DISSOLUTION OF CARBONATES}

Following the Cenozoic occurrences of volcanic claystone, the Miocene to Pleistocene sedimentary column shows an irregular increase in chlorite, illite, and mixed layers. This evolution is a consequence of climatic cooling, which was responsible for the progressive diminution in the intensity of weathering on the continents. As a consequence, the abundance of smectite decreases, while chlorite, illite, and mixed layers become abundant (Chamley, 1979). These minerals are slightly more abundant at Site 532, located at a shallower depth than at Site 530. This difference recalls the observations made on sediments from Leg 74 (Maillot and Robert, in press). Site 532 is more strongly subjected to the Benguela current system, which favors the northern transport of detrital components issued from higher latitudes (Robert, 1980); illite and mixed layers principally.

Previous studies on sediments from the Walvis Ridge recovered during Leg 40 (Maillot, 1980; Maillot and Robert, 1980) have shown that a break occurred in the geochemical index $\mathrm{Mn}^{*}$ during the middle Miocene. Below, the sedimentary column contains abundant transitional elements high $\mathrm{Mn}^{*}$ and above it is poor in these elements low Mn*. The Mn* index is also low in the upper Miocene to Pleistocene section at Site 532 (Fig. 3) and points to a diminution in the oxygen content of oceanic waters, related to the influence of the oxygen-minimum layer or intermediate waters.

At Site 530, variations in the dissolution of carbonates are present in the sediments. From Albian to Coniacian, dissolution is favored by the presence of organic matter and does not depend on the paleodepth of the site. From Coniacian-Santonian to late Campanian, the sediments are not subjected to dissolution effects. Dissolution episodes occur in the upper Maestrichtian to lower Paleocene, middle Paleocene, and middle Eocene to middle Miocene parts of the section. They are caused by a rise in the CCD, as suggested by previous studies (van Andel et al., 1977; LePichon et al., 1978). The last episode of a dissolution occurred during the late Pliocene and corresponds to a local event, as shown during the same period on the Walvis Ridge (Maillot and Robert, in press).

\section{CONCLUSION}

Data obtained by clay mineralogical and inorganic geochemical investigations permit placing the information contained in the sediments recovered during the Leg 75 into the general evolution of the South Atlantic. Data permit the determination of the Cretaceous environment of black-shale deposition, as well as the climatic and morphologic conditions of the continental margins. At the end of the Cretaceous, sediments at Site 530 were influenced by tectonic events and modifications of continental morphology on the African margins and Walvis Ridge, when the ocean width and depth increased. During the Cenozoic, the oceanic environment in this region was marked principally by current-related events; increases in current velocity, existence of upwelling, and dissolution events are related to global climate cooling.

\section{ACKNOWLEDGMENTS}

Thanks are due to the U.S. National Science Foundation for samples from Leg 75. Financial support was provided by the C.N.E.X.O. (France) for geochemical studies. Technical assistance was provided by M. Acquaviva and C. H. Froget for clay minerals analysis, E. Hanton and C. Maillot for geochemical analysis, M. Bocquet for illustrations, J. Carpentier for photographs and F. Dujardin for typing the manuscript.

\section{REFERENCES}

Bausch, W. M., 1968. Recent developments in carbonate sedimentology in Central Europe. In Outlines of Distribution of Strontium in Marine Limestones, Müller, G., and Friedman, G. M. (Eds.), Berlin (Springer-Verlag), pp. 106-115.

Boström, K., 1970. Submarine volcanism as a source of iron. Earth Planet. Sci. Lett., 9:348-384.

Boström, K., Joensuu, O., Valdes, S., Charm, W., and Glacum, R., 1976. Geochemistry and origin of East Pacific sediments sampled during DSDP Leg 34. In Yeats, R. S., Hart, S. R., et al., Init. Repts. DSDP, 34: Washington (U.S. Govt. Printing Office), 559-574.

Boström, K., Joensuu, O., Valdes, S., and Riera, M., 1972. Geochemical history of South Atlantic Ocean sediments since Late Cretaceous. Mar. Geol., 12:85-121.

Boström, K., and Peterson, M. N., 1969. The origin of the aluminum poor ferromanganoan sediments in areas of high heat flow in the East Pacific Rise. Mar. Geol., 7:427-447.

Chamley, H., 1979. North Atlantic clay sedimentation and paleoenvironment since the late Jurassic. In Talwani, M., Hay, W., and Ryan, W. B. F. (Eds.), Deep Drilling Results in the Atlantic Ocean: 
Continental Margins and Paleoenvironment: Washington (Am. Geophys. Union) Maurice Ewing Series, 3:342-360.

Chamley, H., Maillot, H., Duee, G., and Robert, C., in press. Paleoenvironmental history of the Walvis Ridge at the Cretaceous-Tertiary transition from mineralogical and geochemical investigations, In Moore, T. C., Jr., Rabinowitz, P. D., et al., Init. Repts. DSDP, 74: Washington (U.S. Govt. Printing Office).

Chamley, H., and Robert, C., 1979. Late Cretaceous to early Paleocene environmental evolution expressed by the Atlantic clay sedimentation. In Christensen, W. K., and Birkelund, T. (Eds.), Cretaceous-Tertiary Boundary Events Symposium: Copenhagen, 2:71-77. 1982. Paleoenvironmental significance of clay deposits in Atlantic black shales. In Schlanger, S. O., and Cita, M. B. (Eds.) Nature and Origin of Cretaceous Carbon-Rich Facies: London (Academic Press).

Debrabant, P., Chamley, H., Maillot, H., Robert, C., Leroy, P., and Foulon, J., 1981. Influences continentales et marines lors de l'évolution précoce de l'ocean Atlantique. Rapp. Ronéot. A.T.P. C.N.R.S, 4(235).

Diester-Haass, L., and Chamley, H., 1980. Oligocene climatic, tectonic and eustatic history off NW Africa (DSDP Leg 41, Site 369). Oceanol. Acta, 3:115-126.

Diester-Haass, L., and Schrader, H. J., 1979. Neogene coastal upwelling history off Northwest and Southwest Africa. Mar. Geol., 29: 39-53.

Dunoyer de Segonzac, G., 1969. Les minéraux argileux dans la diagenèse. Passage au métamorphisme. Sci. Géol. (Strasbourg, Mém.), 29:320.

Elderfield, H., 1977. The form of manganese and iron in marine sediments. In Glasby, G. P. (Ed.), Marine Manganese Deposits: Amsterdam (Elsevier), pp. 269-290.

Frakes, L. A., 1979. Climates throughout Geologic Time: Amsterdam (Elsevier).

Goldberg, E. D., and Griffin, J. J., 1964. Sedimentation rates and mineralogy in the South Atlantic. J. Geophys. Res., 69:4293-4309.

Krishnaswami, S., 1976. Authigenic transition elements in Pacific pelagic clay. Geochim. Cosmochim. Acta, 40:425-434.

LePichon, X., Melguen, M., and Sibuet, J.-C., 1978. A schematic model of the evolution of the South Atlantic. Advances in Oceanography: London (Charnock and Deacon), pp. 1-48.

Maillot, H., 1979. Etude géochimique de la marge Sud-Est et Atlantique (Leg 40 DSDP). Tème Réun. Ann. Sci. Terre: Lyon (Soc. Géol. France), p. 306.

Maillot, H., 1980. Géochimie des sédiments crétacés et cénozoïques de la marge Atlantique Sud-orientale (Leg 40 DSDP). Rev. Géol. Dyn. Géog. Phys., 22:75-83.

Maillot, H., and Robert, C., 1980. Minéralogie et geochimie des sédiments crétaces et cénozoïques de l'Ocean Atlantique Sud (marge Africaine, dorsale médio-Atlantique). Bull. Soc. Géol. France, 22:777-788.

, in press. Paleoenvironment evolution of the Walvis Ridge deduced from inorganic geochemical and clay mineralogical data. In Moore, T. C., Jr., Rabinowitz, P. D., et al., Init. Repts. DSDP, 74: Washington (U.S. Govt. Printing Office).

Maxwell, A. E., Von Herzen, R. P., et al., 1970. Init. Repts. DSDP, 3: Washington (U.S. Govt. Printing Office).

Melguen, M., 1978. Facies evolution, carbonate dissolution cycles in sediments from the eastern South Atlantic (DSDP Leg 40) since the Early Cretaceous. In Bolli, H. M., Ryan, W. B. F., et al., Init. Repts. DSDP, 40: Washington (U.S. Govt. Printing Office), 981-1024.

Melguen, M., LePichon, X., and Sibuet, J.-C., 1978. Paléoenvironnement de l'Atlantique Sud. Bull. Soc. Geol. France, 20:471-489.

Mercer, J. H., 1978. Glacial development and temperature trends in the Antarctic and in South America. In Van Zinderen Bakker, E.
M. (Ed.), Antarctic Glacial History and World Paleoenvironments: Rotterdam (A. A. Balkema), pp. 73-79.

Millot, G., 1964. Géologie des Argiles: Paris (Masson).

Natland, J. H., 1978. Composition, provenance and diagenesis of $\mathrm{Cre}-$ taceous clastic sediments drilled on the Atlantic continental rise off southern Africa, DSDP Site 361: Implications for the early circulation of the South Atlantic. In Bolli, H. M., Ryan, W. B. F., et al., Init. Repts. DSDP, 40: Washington (U.S. Govt. Printing Office), 1025-1061.

Nekrassov, B., 1966. Chimie Minérale: Généralites et Étude des Éléments: Moscow (Editions de Moscou).

Odin, G. S., and Giresse, P., 1972. Formation de minéraux phylliteux (benthiérine, smectites ferrifères, glauconite ouverte) dans les sédiments du golfe de Guinée. C. R. Acad. Sci. (Paris), 275:177-180.

Paquet, $\mathrm{H}, 1969$. Evolution géochimique des minéraux argileux dans les altérations et les sols des climats méditerranéens et tropicaux à saisons contrastées. Sci. Géol., Mém. 30. (Strasbourg).

Pedro, G., 1968. Distribution des principaux types d'alteration chimique à la surface du globe. Presentation d'une esquisse geographique. Rev. Geogr. Phys. Geol. Dyn., 10:457-470.

Robert, C., 1980. Climats et courants cenozoïques dans l'Atlantique Sud d'après l'etude des minéraux argileux (Legs 3, 39 et 40 DSDP). Oceano. Acta, 3:369-376.

1981. Santonian to Eocene palaeogeographic evolution of the Rio Grande Rise (South Atlantic) deduced from clay mineralogical data (DSDP Legs 3 and 39). Paleogeog., Paleoclimatol., Paleoecol., 33:311-326.

Robert, C., Herbin, J. P., Deroo, G., Giroud d'Argoud, G., and Chamley, H., 1979. L'Atlantique Sud au Crétacé d'après l'étude des minéraux argileux et de la matière organique (Legs 39 et 40 DSDP). Oceanog. Acta, 2:209-218.

Robert, C., and Maillot, H., in press. Paleoenvironmental significance of clay mineralogical and geochemical data, Southwest Atlantic (DSDP Legs 36 and 71). In Ludwig, W. J., Krashenninikov, V. A., et al., Init. Rep. DSDP, 71: Washington (U.S. Govt. Printing Office).

Sibuet, J.-C., and Mascle, J., 1978. Plate kinematic implications of Atlantic equatorial fracture zone trends. J. Geophys. Res., 83: 3401-3421.

Siesser, W. G., 1980. Late Miocene origin of the Benguela upwelling system off Northern Nannibia. Nature, 208:283-285.

Sigl, W., Chamley, H., Fabricius, F., Giroud d'Argoud, G., Müller, J., 1978. Sedimentology and environmental conditions in sapropels. In Hsü, K. J., Montadert, L., et al., Init. Repts. DSDP, 42, Pt. 1: Washington (U.S. Govt. Printing Office), 445-464.

Trauth, N., 1977. Argiles évaporitiques dans la sédimentation carbonatée tertiaire. Bassins de Paris, de Mormoiron et de Salinelles (France); Jbel Ghassoul (Maroc). Sci. Geol., Mém. (Strasbourg), 49.

Turekian, K. K., 1965. Some aspects of the geochemistry of marine sediments. In Reilly, J. P., and Skirrow, G. (Eds.), Chemical Oceanography: London (Academic Press), 2:81-126.

van Andel, Tj. H., Thiede, J., Sclater, J. G., and Hay, W. W., 1977. Depositional history of the South Atlantic ocean during the last 125 million years. J. Geol., 85:651-698.

Vine, J. D., and Tourtelot, E. R., 1970. Geochemistry of black shales deposits. A summary report. Econ. Geol., 65:253-272.

Wedepohl, K. H., 1978. Manganese: Abundance in common sediments and sedimentary rocks. Handbook of Geochemistry: Berlin (Springer-Verlag), pp. 1-17.

Date of Initial Receipt: March 16, 1982 

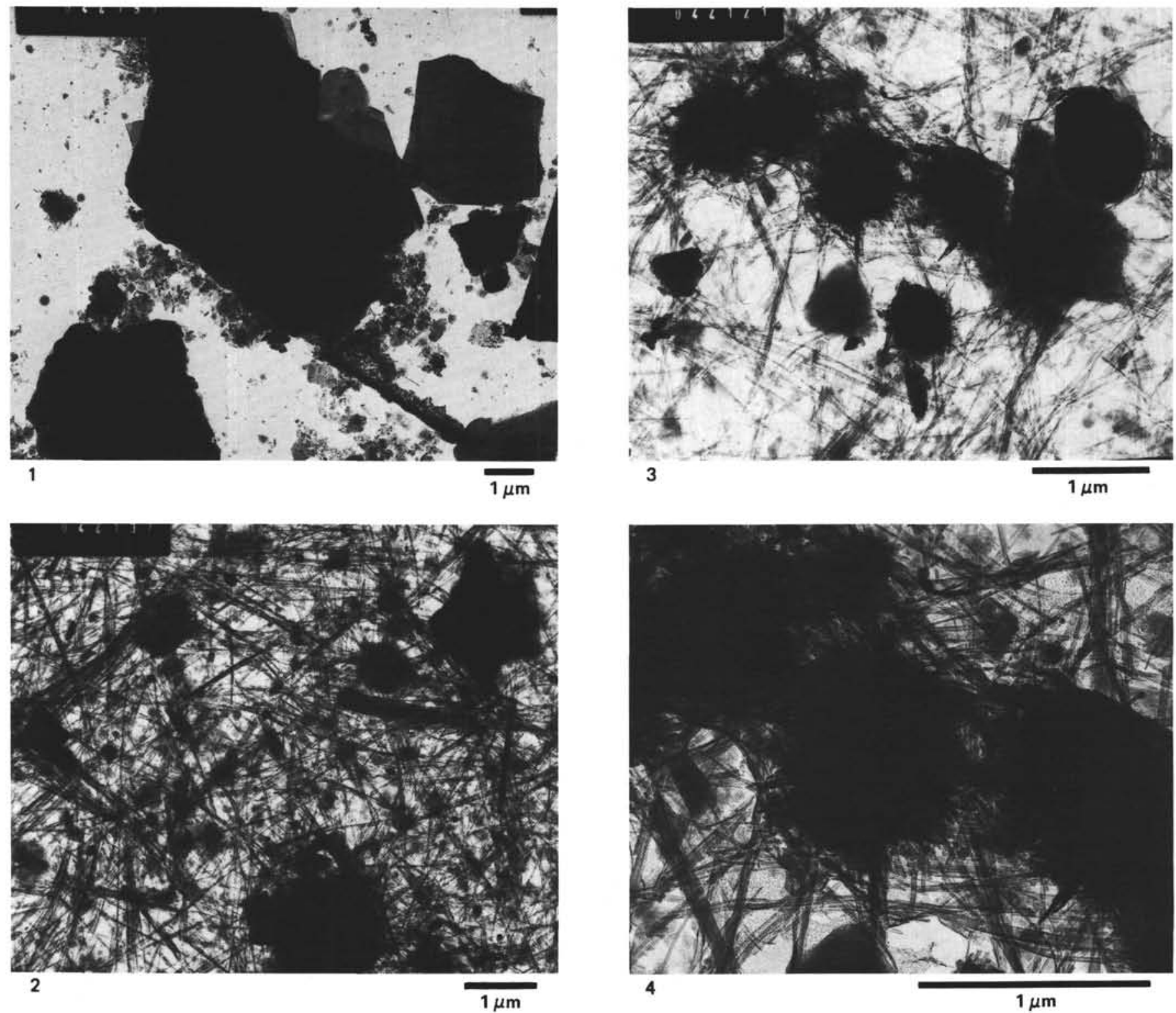

Plate 1. Electronmicrographs. 1. Sample 530B-22-3, $71 \mathrm{~cm}(\times 8,000)$; early Pleistocene; well-shaped particles of illite, fleecy particles of smectite, and fragments of diatoms. 2. Sample $530 \mathrm{~A}-39-2,83 \mathrm{~cm}(\times 12,500)$; early Eocene; palygorskite in long and straight fibers, smectite with blurred contours, and well-shaped illite. 3. Sample 530A-39-2, $83 \mathrm{~cm}(\times 20,000)$; early Eocene; Palygorskite in long and straight fibers, smectite with blurred contours, and well-shaped illite. (Some fibers appear to grow at the periphery of dense particles.) 4 . Sample 530A-39-2, 83 cm $(\times 40,000)$; early Eocene; Fibers of palygorskite growing at the periphery of dense particles (detail of Fig. 3 ). 

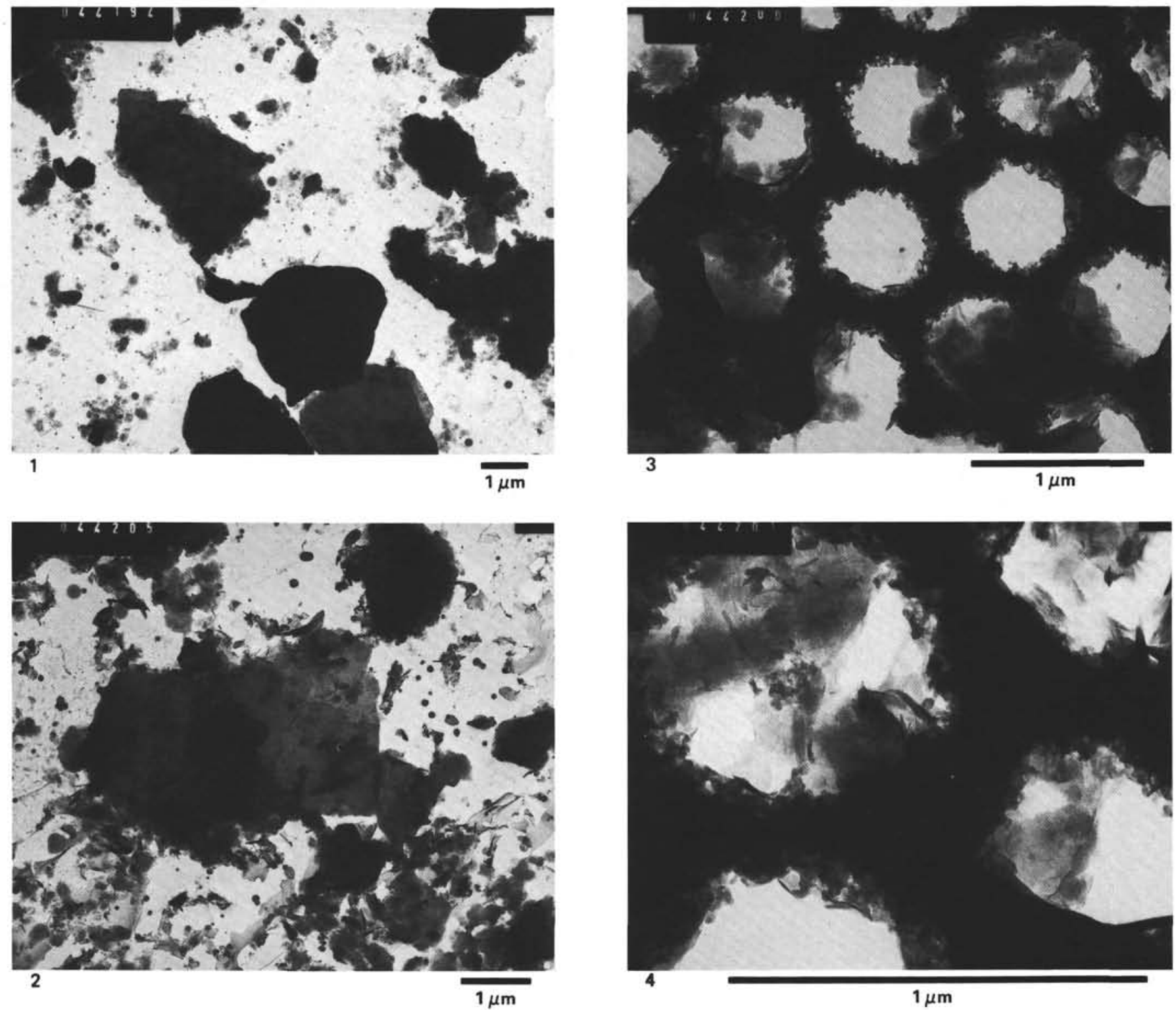

Plate 2. Electronmicrographs. 1. Sample 532-4-3, $105 \mathrm{~cm}(\times 8,000)$; late Pleistocene; well-shaped particles of illite, small particles of chlorite or kaolinite, and smectite with blurred contours. 2. Sample 532-56-2, $24 \mathrm{~cm}(\times 12,500)$; early Pliocene; well-shaped particles of illite, smectite with blurred contours, and fragments of diatoms. 3. Sample 532-15-3, $40 \mathrm{~cm}(\times 31,500)$; early Pleistocene; fragment of diatom with traces of dissolution, and clay particles with blurred contours, probably smectite. 4. Sample 532-15-3, $40 \mathrm{~cm}(\times 75,000)$; early Pleistocene; fragment of diatom with traces of dissolution and clay particles with blurred contours or in short fibers, probably smectite (detail of Fig. 3). 